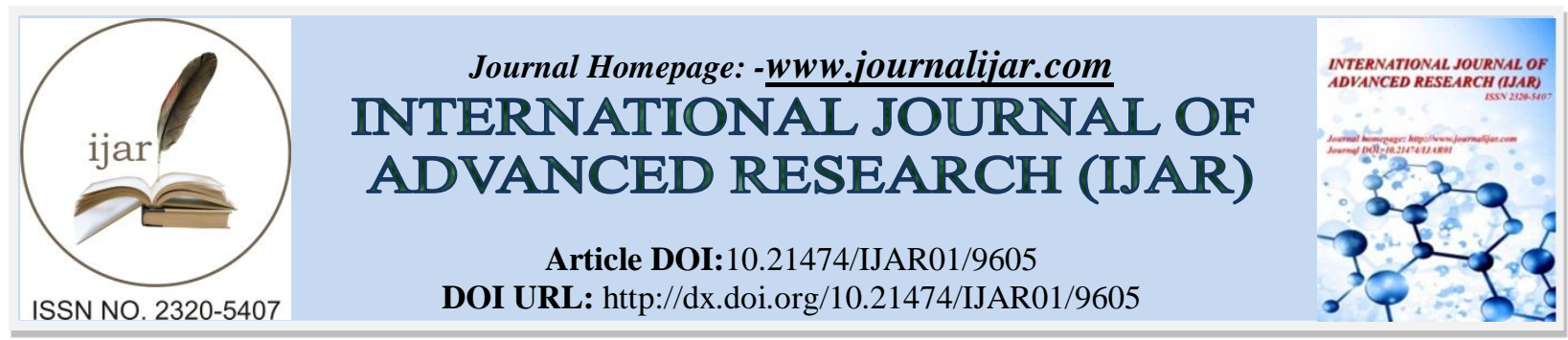

RESEARCH ARTICLE

\title{
PARKING PROBLEMS IN INDIA - MEASURING THE MONETARY LOSS.
}

\section{Mr.Jovit Manjaly ${ }^{1}$ and Dr.Sebastian Tharapil Joseph ${ }^{2}$.}

1. Ph.d Scholar Department of Business Studies, JSBS Sam Higginbottom University of Agriculture Technology \& Sciences.

2. Assistant Professor (Sr.) Department of Business Studies, JSBS Sam Higginbottom University of Agriculture Technology \& Sciences.

\section{Manuscript Info}

Manuscript History

Received: 20 June 2019

Final Accepted: 22 July 2019

Published: August 2019

\section{Abstract}

Copy Right, IJAR, 2019,. All rights reserved.

\section{Introduction:-}

India, the second most populated country in the world, houses more than 40 million vehicles, is the only country which saw a growing car sales even during the recession and recorded the highest sales volume during 2009 and 2010. India has a strong domestic market, and this growth is expected to sustain and increase over the next few years, given that India's car per capita ratio is currently among the lowest in the world's top 10 auto markets.

All the cities in India face severe parking problems. Though parking has negligible effect on quality of transport but there is damage to the life of engine due to parking. Due to anonymous increase of traffic in India, parking has become the new problem along with pollution and poor quality roads. There are two types of parking's, they are off street parking and the other is on street parking. Off street parking is common in big shopping malls and theatres and huge offices which are used by employees \& customers, on the other hand on street parking is traffic problem causing as the parking is directly controlled by market forces, with individual parking and hence has high demand and is considered as public property. Some might argue that parking is one of the lesser woes of urban transport, but this view has led to its exclusion from the policy frame work, causing much traffic. This results in poor quality urban transport, misuse of land and increasing social and environmental costs.

All the urban areas in India face serious parking issues. Despite the fact that parking has irrelevant impact on nature of transport yet there is harm to the life of motor because of parking. Because of unknown increment of activity in India, parking has turned into the new issue alongside pollution and low quality streets. Presently $-\mathrm{a}-$ days parking issue is identified with space so we ought to minimize the space to decline the parking issues due absence of parking there will be an issue of fuel misfortune and low air quality or clogging. So in a few urban areas, pay for the utilization of parking is additionally been presented in occupied markets as this the expense of the area is discounted and there will be control of interest and keeping the business sector from misshaped. The foundations for parking lack are because of few doubts, for example- Parking is open property and fleeting answers for long haul issues that is by taking impermanent activities.

Mending the ways to solve this issue, some points to work on can be seen as - Expanding the parking spaces so more vehicles can be stopped and improving openness and passerby ways around parking spaces to make it more advantageous to stroll from parking space to the objective. This diminishes the drawback of parking in a space that may not be near the fancied area. 
Most extreme use of accessible space so, we can spare the extra burden on parking administration. It is possible by more use of open transportation than private transportation as it involves both expense and financial. Charge drivers straight forwardly for utilizing parking space when not required. This will encourage quick recuperation of expense and will likewise go about as an instrument of interest administration. The parking spaces in business regions ought to be valued higher to guarantee the space of need clients and customers of the specific quit/building.

\section{Current Scenario in India}

Now - a - days parking problem is related to space so we should minimize the space to decrease the parking problems due lack of parking there will be a problem of fuel loss and low air quality or congestion. So in some cities, pay for the usage of parking is also been introduced in busy markets as this the cost of the land is refunded and there will be control of demand and preventing the market from distorted. For its maintenance where the cost is not so high and no free, researches are being done to reduce the area. Fundamentally parking is a problem of space. With the growing culture of automobile dependency in Indian cities, the demand for parking spaces are sky rocketed. This is especially because the infrastructural growth of our cities is unable to keep up with the growing demand for spaces to park. The resultant scarcity of parking space has begun to spill over to other aspects of urban life in form of congestion, fuel loss, dispersed land use and low air quality. So as long as there is inexpensive provision for parking, there will be an increase in usage of private vehicles, further abetting the problem. Therefore, it is imperative to arrive at a solution that on one hand provides space for parking while simultaneously managing demand for parking on the other.

On a normal working day, 40 per cent of the road space in any average-sized Indian city is used for parking rather than for movement of traffic. With every middle class family affording a car, the number of four-wheelers being added to the vehicular population is simply shooting through the roof. Going by the trend, no amount of space will be sufficient to accommodate stationary vehicles, thereby squeezing the movement of public transport to narrower lanes.

\section{Objective of the study:}

1. To find out the problems, causes and effects of non-parking Indians.

2. To find out how proper parking system contributes to the development of India.

3. To find out the present scenario of government parking system and loss to them in absence of proper parking.

\section{Review Of Litrature}

(Agarwal, 2006) studies in the study which was carried out for the Ministry of Urban Development, covering 21 cities in the country, suggests that more than 75 per cent of the trips in a city are on account of either employment or education. Per capita trip rates range from 0.72 to 1.79 per day (RITES 1998). Over 30 per cent of the total trips are undertaken by walking and the share tends to reduce as city size grows and the share of trips by public transport goes up significantly as city size goes up.

(Nandekar \& Raut, 2012) studied the modern sophisticated parking system with space management based on IR and Ultrasonic sensor network. In this system shortest path of the slot can be monitored, system helps us to prevent the vehicle from theft also used to model the space of the slot as per the width of the vehicle. This system is centrally controlled by WSN and Microcontroller and the display shows that availability of slot as per the width as well as the payment of the parked vehicle at the entry. This system is very effectively useful as compared to the existing parking system because it uses to minimize the time consumed for finding the nearest available space,

(Kolhar, 2012) studies about problems with current parking practices with the parking accumulation and supply survey in Dharwad.WTP survey was conducted to know the willingness of the potential user's appropriate parking fee for the new services. Specific parking management strategies (short term, medium term and long term) and the way they can be implemented are discussed.

(Simons \& Lelekis, 2013) revealed in their study Parking Strategy: a coming of age, trying to balance the parking and travel demand needs (wants) of the community. While businesses and the community continue to want convenient and low cost parking, the increasing growth of Darwin as a vibrant city center, and pressure to operate existing Council car parks in a commercial (competitive) environment, demanded a holistic review of the Darwin CBD Parking Strategy. 
(Simićević, Vukanović, \& Milosavljević, 2013)studies in the paper, based on stated preference data and using a logistic regression, a model to predict the effects of introducing or changing the parking price and time limitation was developed. The results show that parking prices affect car usage, while time limitations determine the type of parking used (on-street or off-street). A positive finding for policy makers is that users with work are more sensitive to parking measures than are other users, so parking measures can be used to manage user categories. Although there is a concern that parking policy can jeopardize the attractiveness and efficiency of a zone, the results show that a very small number of users would give up travelling into the zone.

(Litman, 2013) in his report summarizes the book, Parking Management Best Practices (Planners Press, 2006), which describes and evaluates more than two-dozen such strategies. It investigates problems with current parking planning practices, discusses the costs of parking facilities and the savings that can result from improved management, describes specific parking management strategies and how they can be implemented, discusses parking management planning and evaluation, and describes how to develop the optimal parking management program in a particular situation. Cost-effective parking management programs can usually reduce parking requirements by $20-40 \%$ compared with conventional planning requirements, providing many economic, social and environmental benefits.

(Dawra \& Kulshreshtha, 2017) studies about the issues the Indian cities are facing due to ongoing growth of parking demands and the best possible solutions that can be placed in context of it. The current approach of increasing the number of parking lots and reduction in parking rates to keep up with the rising demand doesn't solve the problem completely.

(Kotb, Shen, Zhu, \& Huang, 2016) introduced a new smart parking system that is based on intelligent resource allocation, reservation, and pricing. The proposed system solves the current parking problems by offering guaranteed parking reservations with the lowest possible cost and searching time for drivers and the highest revenue and resource utilization for parking managers. Newfair pricing policies are also proposed that can be implemented in practice.

(Alkheder, Al Rajab, \& Alzoubi, 2016) aimed towards the reduced applicability of paid parking system inside the city, named MAWAQIF at ABU DHABI. This article concentrates on this direction and focuses on two aspects firstly survey and then preparing a technical framework or developing an intelligent mobile application for improving the indoor parking management system in Abu Dhabi was developed. Results indicate that the proposed mobile application will help in reducing the time wasted in searching for parking and will increase the efficiency of the parking system in Abu Dhabi.

(Chen, 2017) suggested to establish emergency linkage mechanism between large parking lot, parking information, timely integration of related scientific allocation and scheduling parking space, through the Internet, radio, mobile communication and information display area parking release parking space and parking guidance information, where there is a parking space, where prices are lower, the owner may at any time the query, thus reducing the invalid traffic vehicles by looking for parking Spaces, improve the utilization rate of parking Spaces to reduce the difficulty of parking, reduce the resulting congestion and illegal, in order to make full use of existing resources of urban parking.

\section{Research methodology:- Area of reasearch}

The research was conducted in the area related to parking problems in India and their solution. The whole study describes major and minor problems of non-parking Indians. It also focuses on the various rules and regulations of the parking, and how it generates income through proper parking system, also highlights the general public on the most traffic areas of Allahabad.

\section{Type Of Reserch}

The topic for the research is to study the nature of the non-parking Indians. The nature of the study is the theoretical and descriptive. So the conduct of the research study the type of research is suitable for descriptive research only. The data are collected from websites, journals, research paper, surveys, questionnaire etc. the descriptive research has met the requirements of research study. 


\section{Sample size:}

the data is being conducted from the 250 respondents.

\section{Sampling techniques:}

In this study, the population is infinite in nature So, Sampling has been done through Random Sampling.

\section{Research area: Allahabad}

Data collection methods:

For the study purpose both primary and secondary data are used. The primary data collected through survey and observation and also the questionnaire. The secondary data collected from records, website, journals, published papers. The primary and secondary data have been collected to cover every aspects of the study. These data used in combination as per the need of the study.

Data obtained from all the parking survey analyzed in term of computation of various parking characteristics. Study of available reports, plans, survey data and statistics related to parking problems were identified, compiled and reviewed. The parking rules and regulation and practices were studied. In addition, many public servants were contacted for collection of secondary data.

\section{Research Tools}

For the collection of data following tools have been used

1. Questionnaire: the primary data is collected from structured questionnaire through interview and the question will be prepared considering the various class of respondents.

2. Observation: by locally observing the problems related to parking problem in local area.

3. Internet

\section{Section I. Personal Information}

Demographic profile of respondents

Table 1.1:-Occupation

\begin{tabular}{|c|l|c|c|c|c|}
\hline \multicolumn{2}{|c|}{} & Frequency & Percent & Valid Percent & Cumulative Percent \\
\hline \multirow{6}{*}{ Valid } & Service & 27 & 8.0 & 8.0 & 8.0 \\
\cline { 2 - 6 } & Businessman & 16 & 4.7 & 4.7 & 12.7 \\
\cline { 2 - 6 } & Professional & 33 & 9.7 & 9.7 & 22.4 \\
\cline { 2 - 6 } & Retired & 28 & 8.3 & 8.3 & 30.7 \\
\cline { 2 - 6 } & Student & 235 & 69.3 & 69.3 & 100.0 \\
\cline { 2 - 6 } & Total & 339 & 100.0 & 100.0 & \\
\hline
\end{tabular}

The above table 1.1 shows that $69.32 \%$ majority of the respondents are students. While, professional, retired and service are $9.7 \%, 8.7 \%$ and 8.0 respectively. $4.7 \%$ of respondents are businessman.

Table 1.2:-Gender

\begin{tabular}{|l|l|r|r|r|r|}
\hline \multicolumn{2}{|c|}{} & Frequency & Percent & Valid Percent & Cumulative Percent \\
\hline \multirow{3}{*}{ Valid } & Male & 190 & 56.0 & 56.0 & 56.0 \\
\cline { 2 - 6 } & Female & 149 & 44.0 & 44.0 & 100.0 \\
\cline { 2 - 6 } & Total & 339 & 100.0 & 100.0 & \\
\hline
\end{tabular}

The above table 1.2 shows that majority of the study comprised on females with $56 \%$ and males are $44 \%$.

Table 1.3:-Education

\begin{tabular}{|l|l|r|r|r|r|}
\hline \multicolumn{2}{|c|}{ Education } \\
\hline \multirow{2}{*}{ Valid } & High-School & \multicolumn{1}{c|}{ Frequency } & Percent & Valid Percent & Cumulative Percent \\
\cline { 2 - 6 } & Intermediate & 56 & 16.5 & 16.5 & 16.5 \\
\hline
\end{tabular}




\begin{tabular}{|l|l|r|r|r|r|}
\hline & Graduate & 146 & 43.1 & 43.1 & 64.6 \\
\cline { 2 - 6 } & $\begin{array}{l}\text { Post- } \\
\text { Graduate }\end{array}$ & 118 & 34.8 & 34.8 & 99.4 \\
\cline { 2 - 6 } & Total & 339 & 100.0 & 100.0 & \\
\hline
\end{tabular}

The above table 1.3 indicates that $43 \%$ respondents are graduates, $34.8 \%$ are post-graduates respondents and 16.5 respondents are upto high school and rest $5.0 \%$ respondents are intermidiate.

Table 1.4:-Age

\begin{tabular}{|l|l|r|r|r|r|}
\hline \multicolumn{2}{|c|}{} & Frequency & Percent & Valid Percent & \multicolumn{1}{c|}{ Cumulative Percent } \\
\hline Valid & $\mathbf{1 8 - 2 5}$ & 187 & 55.2 & 55.2 & 55.2 \\
\cline { 2 - 6 } & $\mathbf{2 6 - 3 5}$ & 73 & 21.5 & 21.5 & 76.7 \\
\cline { 2 - 6 } & $\mathbf{3 6 - 4 5}$ & 42 & 12.4 & 12.4 & 89.1 \\
\cline { 2 - 6 } & Above 45 & 37 & 10.9 & 10.9 & 100.0 \\
\cline { 2 - 6 } & Total & 339 & 100.0 & 100.0 & \\
\hline
\end{tabular}

The above table 1.4 indicates that the $55.2 \%$ of respondents are in the age group of $18-25$ years, $21.5 \%$ of the respondents are in the age group of 26-35 years, the age group between 36-45 are $12.4 \%$ and $10.9 \%$ of respondents are above 45 years.

Section II General Information

Table 2.1:-Is this your property?

\begin{tabular}{|c|c|c|c|c|c|}
\hline \multicolumn{2}{|c|}{} & Frequency & Percent & Valid Percent & Cumulative Percent \\
\hline Valid & Home & 51 & 51.0 & 51.0 & 51.0 \\
\cline { 2 - 6 } & Business & 13 & 13.0 & 13.0 & 64.0 \\
\cline { 2 - 6 } & Other & 23 & 23.0 & 23.0 & 87.0 \\
\cline { 2 - 6 } & Both & 13 & 13.0 & 13.0 & 100.0 \\
\cline { 2 - 6 } & Total & 100 & 100.0 & 100.0 & \\
\hline
\end{tabular}

The above table 2.1 shows that the $51 \%$ of the respondents have their home, $13 \%$ of the respondents are having business and home property both and rest $23 \%$ are others.

Table 2.2:-How many vehicles in the above Property?

\begin{tabular}{|c|c|c|c|c|c|}
\hline \multicolumn{2}{|c|}{} & Frequency & Percent & Valid Percent & Cumulative Percent \\
\hline \multirow{6}{*}{ Valid } & None & 22 & 22.0 & 22.0 & 22.0 \\
\cline { 2 - 6 } & One & 23 & 23.0 & 23.0 & 65.0 \\
\cline { 2 - 6 } & Two & 24 & 24.0 & 24.0 & 100.0 \\
\cline { 2 - 6 } & Three & 31 & 31.0 & 31.0 & 100.0 \\
\cline { 2 - 6 } & Total & 100 & 100.0 & & \\
\hline
\end{tabular}

The above table 2.2 indicates that the $31 \%$ majority of the respondents having three vehicles they owned. $24 \%$ of the majority of the respondents owned just two vehicles, $23 \%$ of the majority owned only one vehicle and $22 \%$ of the majority have no vehicle in the above property.

Table 2.3:-How many of these are parked on the street?

\begin{tabular}{|c|c|c|c|c|c|}
\hline \multicolumn{2}{|c|}{} & Frequency & Percent & Valid Percent & Cumulative Percent \\
\hline Valid & None & 59 & 59.0 & 59.0 & 59.0 \\
\cline { 2 - 6 } & One & 17 & 17.0 & 17.0 & 76.0 \\
\cline { 2 - 6 } & Two & 11 & 11.0 & 11.0 & 87.0 \\
\cline { 2 - 6 } & Three & 13 & 13.0 & 13.0 & 100.0 \\
\cline { 2 - 6 } & Total & 100 & 100.0 & 100.0 & \\
\hline
\end{tabular}

The above table shows that the $59 \%$ of the respondents don't parked their vehicle on the street and rest $17 \%, 13 \%$ and $11 \%$ of the respondents parked their vehicle on the street. 
Table 2.4:-Do you have access to off-street parking facilities

\begin{tabular}{|c|c|c|c|c|c|}
\hline \multicolumn{2}{|c|}{} & Frequency & Percent & Valid Percent & Cumulative Percent \\
\hline \multirow{3}{*}{ Valid } & Yes & 32 & 32.0 & 32.0 & 32.0 \\
\cline { 2 - 6 } & No & 68 & 68.0 & 68.0 & 100.0 \\
\cline { 2 - 6 } & Total & 100 & 100.0 & 100.0 & \\
\hline
\end{tabular}

The above table 2.4 shows that the $32 \%$ of the respondents they didn't have access to off- street parking facility but $68 \%$ majority of the respondents have access to the off-street parking facilities.

Table 3.1:-Are you happy with the current parking situation in your road?

\begin{tabular}{|c|c|c|c|c|c|}
\hline & & Frequency & Percent & Valid Percent & Cumulative Percent \\
\hline \multirow[t]{3}{*}{ Valid } & Yes & 43 & 42.6 & 42.6 & 42.6 \\
\hline & No & 57 & 56.4 & 56.4 & 99.0 \\
\hline & Total & 101 & 100.0 & 100.0 & \\
\hline
\end{tabular}

\section{Section III. Parking Issue}

The above table 3.1 shows that the $42.6 \%$ majority of the respondents are happy with the current parking situation on road and rest $56 \%$ of the respondents are not happy with the current parking situation.

Table 3.2:-Would you like parking issues in your road to be investigated further?

\begin{tabular}{|l|l|r|r|r|r|}
\hline \multicolumn{2}{|c|}{} & Frequency & Percent & Valid Percent & Cumulative Percent \\
\hline Valid & Yes & 73 & 72.3 & 72.3 & 72.3 \\
\cline { 2 - 6 } & No & 27 & 26.7 & 26.7 & 99.0 \\
\cline { 2 - 6 } & Total & 101 & 100.0 & 100.0 & \\
\hline
\end{tabular}

The above table 3.2 indicates that the $72.3 \%$ majority of the respondents are like to investigate future current parking issues. And $27 \%$ of the respondents are not likely feel that the parking issue should be investigated further.

Table 3.3:-Do you regularly find it difficult to find a space to park in your road?

\begin{tabular}{|c|l|r|r|r|rc|}
\hline \multicolumn{2}{|c|}{ Valid } & Yes & Frequency & Percent & Valid Percent & Cumulative Percent \\
\cline { 2 - 7 } & No & 66 & 65.3 & 65.3 & 65.3 \\
\cline { 2 - 7 } & Total & 34 & 33.7 & 33.7 & 99.0 \\
\hline
\end{tabular}

The above table 3.3 shows that the $65.4 \%$ of the majority of the respondents faces problem in finding a space to park their vehicle on road and $33.7 \%$ of the respondents easily find a space to park on road.

Table 3.4:-Do you ever have to park in your neighboring roads because there is no space in your own road?

\begin{tabular}{|c|l|r|r|r|rc|}
\hline \multicolumn{2}{|c|}{} & Frequency & Percent & $\begin{array}{c}\text { Valid } \\
\text { Percent }\end{array}$ & \multicolumn{2}{c|}{ Cumulative Percent } \\
\hline \multirow{3}{*}{ Valid } & Yes & 71 & 70.3 & 70.3 & 70.3 \\
\cline { 2 - 7 } & No & 29 & 28.7 & 28.7 & 99.0 \\
\cline { 2 - 7 } & Total & 101 & 100.0 & 100.0 & \\
\hline
\end{tabular}

The above table 3.4 indicates that the $70.3 \%$ of the respondents park their vehicle on the neighboring road. While $28.7 \%$ of the majority of the respondents easily find a space to park on their own locality

Table 3.5:-a) Do you find vehicles are parked obstructing, unfairly and/or inconsiderately in your road?

\begin{tabular}{|l|l|r|r|r|r|}
\hline \multicolumn{2}{|c|}{} & \multicolumn{1}{|c|}{ Frequency } & Percent & Valid Percent & Cumulative Percent \\
\hline \multirow{3}{*}{ Valid } & Yes & 79 & 78.2 & 78.2 & 78.2 \\
\cline { 2 - 7 } & No & 21 & 20.8 & 20.8 & 99.0 \\
\cline { 2 - 7 } & Total & 101 & 100.0 & 100.0 & \\
\hline
\end{tabular}


The above table 3.5 a) indicates that the $78 \%$ of the majority of the respondent's state that the vehicle are obstructing, unfairly parked on road, while $20 \%$ of the majority didn't agree with the above statement.

Table 3.5:-b) If yes, please give details.

\begin{tabular}{|c|c|c|c|c|c|}
\hline & & Frequency & Percent & Valid Percent & $\begin{array}{l}\text { Cumulative } \\
\text { Percent }\end{array}$ \\
\hline \multirow[t]{8}{*}{ Valid } & Footway parking & 11 & 10.9 & 10.9 & 10.9 \\
\hline & Double Parking & 13 & 12.9 & 12.9 & 23.8 \\
\hline & $\begin{array}{l}\text { Vehicles left for long } \\
\text { period of time }\end{array}$ & 18 & 17.8 & 17.8 & 41.6 \\
\hline & $\begin{array}{l}\text { Inconsiderate } \\
\text { residents/visitors }\end{array}$ & 24 & 23.8 & 23.8 & 65.3 \\
\hline & $\begin{array}{l}\text { Taking up more space } \\
\text { than necessary }\end{array}$ & 10 & 9.9 & 9.9 & 75.2 \\
\hline & $\begin{array}{l}\text { Obstruction to } \\
\text { through traffic }\end{array}$ & 15 & 14.9 & 14.9 & 90.1 \\
\hline & Other & 9 & 8.9 & 8.9 & 99.0 \\
\hline & Total & 101 & 100.0 & 100.0 & \\
\hline
\end{tabular}

The above table 3.5 (b) state that the $23 \%$ of the majority of the respondent's state that the most of the vehicle are parked obstructively because of inconsiderate visitor. $17 \%$ of the respondent indicated that the vehicle is left for the longer period of time. $12 \%$ of the vehicles are unfair parked at double parking. $10 \%$ of the vehicles are parked at the footway parking and $9.9 \%$ of the respondents take more spaces than necessary to park their vehicle and $8.9 \%$ are the other reason obstructing, unfairly and inconsiderately on road.

Table 3.10:-(a) Do you find it difficult to turn at junctions in your road due to parked vehicles?

\begin{tabular}{|c|l|r|r|r|r|}
\hline \multicolumn{2}{|c|}{} & \multicolumn{1}{|c|}{ Frequency } & Percent & $\begin{array}{c}\text { Valid } \\
\text { Percent }\end{array}$ & Cumulative Percent \\
\hline \multirow{3}{*}{ Valid } & Yes & 74 & 73.3 & 73.3 & 73.3 \\
\cline { 2 - 6 } & No & 23 & 22.8 & 22.8 & 96.0 \\
\cline { 2 - 6 } & Total & 101 & 100.0 & 100.0 & \\
\hline
\end{tabular}

The table 3.10(a) indicates that the $73 \%$ of the majority of the respondents are find difficulty and $23 \%$ of the majority of the respondents didn't find difficulty to park their vehicle at the junction.

Table 3.10:-(b) What are your reasons for parking on the roadside rather than the car parks?

\begin{tabular}{|c|c|c|c|c|c|}
\hline & & Frequency & Percent & $\begin{array}{c}\text { Valid } \\
\text { Percent }\end{array}$ & Cumulative Percent \\
\hline \multirow[t]{5}{*}{ Valid } & Only paying a quick visit & 40 & 39.6 & 39.6 & 39.6 \\
\hline & $\begin{array}{l}\text { Don't want to pay for an } \\
\text { hour parking }\end{array}$ & 22 & 21.8 & 21.8 & 61.4 \\
\hline & $\begin{array}{l}\text { I have limited mobility } \\
\text { and its closer to shops }\end{array}$ & 25 & 24.8 & 24.8 & 86.1 \\
\hline & $\begin{array}{l}\text { I struggle to pay parking } \\
\text { charges }\end{array}$ & 13 & 12.9 & 12.9 & 99.0 \\
\hline & Total & 101 & 100.0 & 100.0 & \\
\hline
\end{tabular}

The above table 3.10(b) states that the $37 \%$ of the majority of the respondents parked their vehicle on the roadside rather than the car park for quick visit. $24 \%$ majority of the respondents parked their vehicle on the road side as they think that they have limited mobility and its closer to the shop. $21 \%$ and $13 \%$ of the majority of the respondents parked their vehicle on roadside as they don't want to pay for an hour parking and they struggle to pay for parking charges respectively.

Table3.11:-How often do you park in the on-street spaces?

\begin{tabular}{|l|l|l|l|} 
Frequency & Percent & Valid & Cumulative Percent \\
\hline
\end{tabular}




\begin{tabular}{|l|l|r|r|r|r|}
\hline \multirow{3}{*}{ Valid } & Once a day & 25 & 24.8 & Percent & 24.8 \\
\cline { 2 - 6 } & 2-3 times a week & 26 & 25.7 & 25.7 & 50.5 \\
\cline { 2 - 6 } & At weekends only & 29 & 28.7 & 28.7 & 79.2 \\
\cline { 2 - 6 } & $\begin{array}{l}\text { More than once a } \\
\text { day }\end{array}$ & 20 & 19.8 & 19.8 & 99.0 \\
\cline { 2 - 6 } & Total & 101 & 100.0 & 100.0 & \\
\hline
\end{tabular}

The above table 3.11 states that the $28 \%$ of the majority of the respondents parked their vehicle on the street spaces at weekends only. $26 \%$ of the majority of the respondents parked their vehicle on street spaces 2-3 times a week and $24 \%$ and $20 \%$ of the majority of the parked their vehicle on street once a day and more than once a day respectively.

Table no. 3.13:-When you parked in an on-street space, how long on average do you spend?

\begin{tabular}{|c|l|r|r|r|r|}
\hline \multicolumn{2}{|c|}{} & Frequency & Percent & $\begin{array}{c}\text { Valid } \\
\text { Percent }\end{array}$ & Cumulative Percent \\
\hline \multirow{3}{*}{ Valid } & Upto 10 min. & 36 & 35.6 & 35.6 & 35.6 \\
\cline { 2 - 6 } & $10-20$ min. & 23 & 22.8 & 22.8 & 58.4 \\
\cline { 2 - 6 } & $20-30$ min, & 18 & 17.8 & 17.8 & 76.2 \\
\cline { 2 - 6 } & 30 min. to an hour & 23 & 22.8 & 22.8 & 99.0 \\
\cline { 2 - 6 } & Total & 101 & 100.0 & 100.0 & \\
\hline
\end{tabular}

The table 3.13 shows that the $35 \%$ of the majority of the respondents parked their vehicle on street an average period of $10 \mathrm{~min} .22 \%$ of the majority parked their vehicle on street at an average period of $10-30 \mathrm{~min}$. and $17 \%$ of the majority of the respondents parked their vehicle on street at an average period of $30 \mathrm{~min}$ to an hour.

Table no.3.14:-At what times of day is you most likely to park?

\begin{tabular}{|l|l|r|r|r|r|}
\hline \multicolumn{1}{|c|}{ Valid } & Orequency & Percent & Valid Percent & Cumulative Percent \\
\cline { 2 - 6 } & Between 6-9 am & 24 & 23.8 & 23.8 & 23.8 \\
\cline { 2 - 6 } & Between 9 am - 12 noon & 11 & 10.9 & 10.9 & 34.7 \\
\cline { 2 - 6 } & Between 1 pm to 4pm & 15 & 14.9 & 14.9 & 49.5 \\
\cline { 2 - 6 } & Between 4 pm to 6 pm & 22 & 21.8 & 21.8 & 71.3 \\
\cline { 2 - 6 } & $\begin{array}{l}\text { Between 6 pm to 12 } \\
\text { midnight }\end{array}$ & 11 & 10.9 & 10.9 & 92.2 \\
\cline { 2 - 6 } & Total & 17 & 16.8 & 16.8 & 99.0 \\
\hline
\end{tabular}

The above table no.3.14 state that $24 \%$ of the majority of the respondents most likely to parked their vehicle overnight and $11 \%$ of the majority of the respondents which is least most likely to parked between 6am to 9 am.

Table no 3.15:-Which shops and businesses do you generally use when you park on the street?

\begin{tabular}{|l|l|r|r|r|r|}
\hline \multicolumn{2}{|c|}{} & Frequency & Percent & $\begin{array}{c}\text { Valid } \\
\text { Percent }\end{array}$ & $\begin{array}{c}\text { Cumulative } \\
\text { Percent }\end{array}$ \\
\hline Valid & $\begin{array}{l}\text { Food-Bakery/ Green Grocers/ } \\
\text { Butchers/ Deli/ Health Food }\end{array}$ & 12 & 11.9 & 11.9 & 11.9 \\
\cline { 2 - 6 } & Sports shop/ Heads/ Shoes Shop & 35 & 34.7 & 34.7 & 46.5 \\
\cline { 2 - 6 } & $\begin{array}{l}\text { Books Shop/ Toy shop/ Art and } \\
\text { Crafts/ Cart shops/ Knick-necks }\end{array}$ & 15 & 14.9 & 14.9 & 71.3 \\
\cline { 2 - 6 } & $\begin{array}{l}\text { Art Gallery/Jeweler's/Shopping } \\
\text { Malls }\end{array}$ & 10 & 9.9 & 9.9 & 99.0 \\
\cline { 2 - 6 } & $\begin{array}{l}\text { Coffee shop/ } \\
\text { Restaurant/Pups/Hotels }\end{array}$ & 28 & 27.7 & 27.7 & \\
\hline
\end{tabular}




\begin{tabular}{|l|l|r|r|r|l|}
\hline Total & 101 & 100.0 & 100.0 & \\
\hline
\end{tabular}

The above table 3.15 states $27.7 \%$ that the majority of the respondents parked their vehicle on street which is very close to the coffee shops, restaurant, pups, and hotels. And 34.7\% majority of the respondents parked their vehicle in from of the sports shops, heads, and shoe shops. While, $14 \%$ of the majority of the respondents parked their vehicle on-street which is very close access to the food-bakery, green grocers, butchers, dairy and health food. While $12 \%$ and $9 \%$ of the majority parked their vehicle on-street which is very close to the book shops, toy shops, art and crafts, art and gallery, jewelers shops and at shopping malls respectively.

Table no. 3.16:-In your opinion, how would you describe the number of parked vehicles in the sections of road around your property?

\begin{tabular}{|c|l|r|r|r|r|}
\hline \multicolumn{2}{|c|}{} & \multicolumn{1}{|c|}{ Frequency } & Percent & Valid Percent & \multicolumn{2}{c|}{$\begin{array}{c}\text { Cumulative } \\
\text { Percent }\end{array}$} \\
\hline \multirow{3}{*}{ Valid } & Very High & 32 & 31.7 & 31.7 & 31.7 \\
\cline { 2 - 6 } & High & 35 & 34.7 & 34.7 & 66.3 \\
\cline { 2 - 6 } & Moderate & 13 & 12.9 & 12.9 & 79.2 \\
\cline { 2 - 6 } & Low & 8 & 7.9 & 7.9 & 87.1 \\
\cline { 2 - 6 } & Very Low & 12 & 11.9 & 11.9 & 99.0 \\
\cline { 2 - 6 } & Total & 101 & 100.0 & 100.0 & \\
\hline
\end{tabular}

The above table no. 3.16 indicates that the $34.7 \%$ and $31.7 \%$ majority of the respondents describes that the number of the parked vechile around their property is very high and high.and $12 \%$ and $8 \%$ of the majority sates that the number off vehicle parked around their property is low and very low.

\section{Conclusion:-}

Urban public transport in India is underdeveloped resulting in congestion on roads due to mixed traffic. The unreliable and rudimentary public transport system led to increased dependence in small, motorized vehicle among urban population. The more congestion traffics led to many major accidents. With the phenomenal increase in the personalized vehicle, one of the major problems confronted by the people is the acute shortage of the parking space. The demand for parking has increased in alarming rate across India. There are many disputes over parking spaces.

The proper parking system should be made to solve the non-parking issue. Increasing the parking spaces so that more vehicles can be parked. Improving accessibility and pedestrian paths around parking spaces to make it more convenient to walk from parking space to the destination.

This reduces the inconvenience of parking in a space that may not be very close to the desired location. Well managed parking and parking restraints have many benefits. Benefits to the vehicle users and it reduces traffic chaos. Environment benefits to the non-car users. Proper parking should be made to make the parking problems solved and also to reduce the number of crimes and its give benefit to the government and also general public.

\section{References:-}

1. Agarwal, O. (2006). INDIA INFRASTRUCTURE REPORT 2006. Retrieved from http://www.idfc.com: http://www.idfc.com/pdf/report/IIR-2006.pdf

2. Alkheder, S. A., Al Rajab, M. M., \& Alzoubi, K. (2016). Parking problems in Abu Dhabi, UAE toward an intelligent parking management system "ADIP: Abu Dhabi Intelligent Parking. Alexandria Engineering Journal , 2679-2687.

3. Chen, W. (2017). Urban Parking Problem Analysis and Solving Countermeasures: Taking Xi'an as the Example. 3rd International Conference on Social Science and Technology Education, (pp. 286-291).

4. Dawra, M., \& Kulshreshtha, S. (2017). A Case Study: Growing Parking Issues and Effective Parking Management Strategies. International Journal of Innovative Research in Science, Engineering and Technology, 1792-1798.

5. Kolhar, P. (2012). OFFSTREET PARKING MANAGEMENT PLAN FOR DHARWAD CITY, KARNATAKA, INDIA. Journal of Engineering Research and Studies , 67-71. 
6. Kotb, A. O., Shen, Y. C., Zhu, X., \& Huang, Y. (2016). IParker-A New Smart Car-Parking System Based on Dynamic Resource Allocation and Pricing. IEEE Transactions on Intelligent Transportation Systems , 26372647.

7. Litman, T. (2013). Parking Management Strategies, Evaluation and Planning. Strategies , 1-28.

8. Nandekar, B., \& Raut, R. (2012). A Novel Approach towards Car Parking with Space Conservation. IJECCE , 1650-1653.

9. Sharma, K. M., Prjapat, P., \& Jain, M. (2017). Problem of Parking and their Possible Solutions with Special Reference to Kota City. CPUH-Research Journa , 2 (1), 18-24.

10. Simićević, J., Vukanović, S., \& Milosavljević, N. (2013). The effect of parking charges and time limit to car usage and parking behaviour. Transport Policy, 125-131.

11. Simons, P., \& Lelekis, D. (2013). Darwin CBD Parking Strategy: a coming of age. International Public Works Conference, 2013. Darwin, Northern Territory, Australia. 